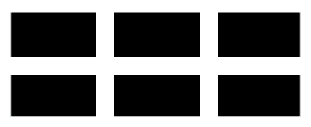

THE WILLIAM DAVIDSON INSTITUTE

AT THE UNIVERSITY OF MICHIGAN BUSINESS SCHOOL

\title{
Targeting Relative Inflation Forecast as Monetary Policy Framework for Adopting the Euro
}

\author{
By: Lucjan T. Orlowski
}

William Davidson Institute Working Paper Number 754

February 2005 
Targeting Relative Inflation Forecast as Monetary Policy Framework for Adopting the Euro

\author{
Lucjan T. Orlowski* \\ Professor of Economics and International Finance, Sacred Heart University, 5151 Park Avenue, \\ Fairfield, CT 06825. USA
}

\begin{abstract}
:
This study proposes relative inflation forecast targeting as an operational framework of monetary policy for adopting the euro by the EU new Member States. This strategy assumes containing differentials between the domestic and the eurozone inflation forecasts as an operational target. A model prescribing the RIFT framework is presented along with a set of appropriate policy indicator variables and instrument rules. The proposed framework advances the strategy based on relatively strict inflation targeting that is currently pursued by some NMS. Several ARCHclass tests in various functional forms are employed for providing preliminary empirical evidence on convergence of inflation differentials relative to the euro area for Poland, Czech Republic and Hungary.
\end{abstract}

JEL classification: E42, E52, E61, F36, P24

Keywords: Inflation targeting; Monetary convergence; Euro adoption; EU new Member States.

* Corresponding author: Lucjan T. Orlowski, Department of Economics and Finance, Sacred Heart University, 5151 Park Avenue, Fairfield, CT 06825. Tel. (203) 371 7858. Fax (203) 3657538.

E-mail address: OrlowskiL@sacredheart.edu

The author is grateful to DIW Berlin - Division of Macroeconomic Analysis and Forecasting for sponsoring this research. 


\section{Introduction}

Over the past fifteen years, eight of the new Member States (NMS) of the European Union (EU) have undergone a remarkable economic transformation gradually dismantling the rigid, ineffective central planning system and building the institutional framework of a modern, competitive market economy. Setting up monetary policies has been an integral part of this reform process. The initial straightforward monetary stabilisation policies based on fixed exchange rates have evolved into more autonomous policies with increasingly flexible currency regimes. By the end of the 1990s, monetary authorities of the Czech Republic and Poland joined a number of other central banks in embracing a framework of direct inflation targeting (DIT), and thus demonstrated their commitment to contain inflation. Hungary followed their footsteps a bit later in 2001. The DIT regimes have helped accomplishing the goal - over the past three years the headline inflation in these NMS has been successfully contained to low single digit levels.

Their formal accession to the EU in May 2004 brought yet another a bit different and perhaps even more challenging task for the policy-makers. They now need to devise a monetary policy framework that is appropriate for navigating the path to the euro adoption, which is expected to take place by the end of the present decade. Yet, neither the historical experience with DIT formulation in industrial countries nor the academic literature on monetary economics offers much guidance in this respect. In fact, the analyses advancing modern inflation targeting regimes have not taken into consideration the issue of monetary convergence to a common currency system. This study attempts to quench this vacuum by proposing an operational framework based on relative inflation forecast targeting (RIFT) as an advancement of current DIT regimes. It is believed that such operational procedure may contribute to an effective monetary convergence of the candidates to the euro.

A key precept of RIFT is that policy-makers develop a system of continuous monitoring and active responding to the differentials between the domestic and the foreign (the eurozone) inflation forecasts for a predetermined time-period. Consistently, a dynamic reduction of these differentials becomes the main operational goal of monetary policy. Such operational framework can be reasonably expected to lead to a perfect identity between long-term inflation targets of the candidate and the common currency area over the time-period preceding the 
expected date of the formal euro adoption. Based on this assumption, the long-term inflation target of the candidate is equal to - or more precisely - 'derived from' that of the eurozone. Monetary authorities of the candidates may use a range of indicator variables including various measures of exchange rate stability, money growth or price stability in addition to the headline inflation, which is considered as a target variable. The proposed RIFT framework is suitable for countries that are currently pursuing DIT strategies and whose financial markets are relatively well-developed thus capable of providing appropriate signals for the modified conduct of inflation-targeting. Such framework may not be a viable policy option for smaller NMS, such as the Baltic States, that pursue a currency board arrangement on their passage toward the euro adoption. Their departure from the present monetary regime would likely entail large shocks to their low-capitalised financial markets.

Section 2 of this paper elaborates the reasons for the functional equilibrium between long-term inflation targets of the candidate country and the eurozone. The model outlining the RIFT framework is presented in Section 3. Exchange rate stability and money growth as the policy indicator variables, along with policy instruments are examined in Section 4. A plausible inception of RIFT depends on a prior record of price stability and a demonstrated functional relationship between the relative inflation forecast (as a target variable), nominal exchange rate and money growth (indicator variables) and interest rates (instrument variables). The actual relationships between these variables in the Czech Republic, Poland and Hungary are assessed in Section 5 by employing the autoregressive conditional heteroscedasticity (ARCH) class models. The concluding Section 6 summarises key findings and presents several policy recommendations for the final passage toward the euro adoption.

\section{Functional Identity between Long-Term Inflation Targets}

Monetary policies in countries presently converging to the euro have undergone a remarkable transition since the inception of economic reforms in the early 1990s. At the early stage of transition, central banks were confronted with the task of containing extremely high inflation stemming mainly from the far-reaching price liberalization. They also encountered a challenge of establishing monetary policy credibility. At the same time, financial markets in these countries were undercapitalised and highly volatile, offering only a limited number of products, all of which curbed the ability of central banks to introduce indirect instruments of the monetary 
policy. Thus in order to accomplish the ambitious goals of curbing inflation and building the initial policy credibility, monetary authorities in these countries opted for hard currency pegs.

As the transition evolved, hard pegs became increasingly burdensome as the combination of fixed exchange rates and the residues of high inflation led to real currency appreciation and, subsequently, to current account deficits and the deteriorating risk structure of capital inflows. These unfavourable developments prompted the monetary authorities to devise various exit strategies from hard pegs toward autonomous monetary policies with flexible exchange rates (Corker, et. al., 2000). After rather unsuccessful experiments with interest rate targeting, monetary base targeting (in Poland), and targeting exchange rate bands with crawling devaluations, central banks of several transition countries with now fairly well-developed financial markets adopted DIT strategies (Masson, 1999; Orlowski, 2001; Jonas and Mishkin, 2003). The Czech National Bank (CNB) did so in January 1998, the National Bank of Poland (NBP) in January 1999, while the National Bank of Hungary (NBH) deferred a similar move until May 2001. The actual implementation of DIT stirred a heated debate over its timing, the exact format and the overall rationale. At least in the case of Poland, the new policy action was characterised as a bit premature by Christofferssen and Wescott (1999) since the country's average monthly annualised CPI headline inflation in 1998 was still running at 11.9 percent and the functional relationship between inflation and other monetary policy variables was imprecise and highly unstable. Without doubt, the three examined countries did not satisfy the prerequisites for DIT inception stated by Mishkin (2000), particularly the requirements of singledigit inflation, a stable relationship between inflation and policy instruments, and the welldefined channels of monetary policy transmission. Yet, their strong commitment to disinflation and confidence about the future monetary stability prevailed over the existing institutional deficiencies (Jonas and Mishkin, 2003).

In spite of the continuous institutional difficulties, the three central banks made courageous moves to embrace DIT. These decisions underpinned their strong commitment to disinflation. In the absence of record of sustainable monetary stability, they could resort only to adopting a strict form of DIT, which assigns full priority to achieving the predetermined inflation target and does not consider alternative policy objectives, such as income growth or currency stability. Yet the sole commitment to disinflation entailed some opportunity costs for the ambitious and at times stretched inflation targets were achieved at the cost of high nominal (and real) interest rates that hampered economic growth (Orlowski, 2003). 
By the time of the formal EU admission in May 2004, the strict DIT policies had accomplished major disinflation tasks in these countries. Inflation was stabilized at low, sustainable levels and risk premia for investors fell significantly, although to the levels still exceeding those in the eurozone. It seems that these policies have laid a favourable ground for advancing to the next stage, which will entail a different set of monetary policy objectives consistent with the general goal of effective convergence to the euro. However, the monetary authorities of the three NMS have yet to articulate an optimal operational framework of monetary policy that would facilitate the convergence process. So far, neither policy makers nor the literature on monetary policy has addressed adequately possible scenarios with respect to achieving the goal of convergence.

This paper proposes a policy framework that is believed to be conducive to effective convergence to the euro. It advances the DIT strategies that are currently pursued by the three NMS. The key analytical assumptions underlying the proposed framework are as follows:

1. From the standpoint of effective convergence to the euro, the long-term inflation targets of the candidates and the eurozone ought to be identical.

2. Continuation of the present strict DIT strategies is likely to yield suboptimal results relative to the main tasks of a smooth convergence to the euro. Stating briefly, it may exacerbate volatility of monetary variables, particularly nominal and real exchange rates, thus elevate risk premia and deteriorate the risk structure of capital inflows.

3. In order to underpin commitment to the convergence process and reduce volatility of key monetary variables, the modified DIT strategy ought to be forward-looking, thus based on reliable inflation forecasts that are properly communicated to the public at large.

4. The new policy shall be based on a flexible variant of DIT, for explicit inflation targets will continue to function as a primary policy goal. However, stability of nominal exchange rate ought to be taken into consideration as an indicator variable, since the objective of mitigating the exchange rate volatility is strictly linked with a smooth final passage toward the euro.

These assumptions lead to devising a modified DIT framework that is outlined below. It shall be noted that this exercise is not rooted in the existing literature that pertains solely to further evolution of modern fully autonomous inflation targeting regimes applicable to large, seemingly closed economies. The majority of theoretical models and empirical research relate to 
such economies (Bernanke, et.al., 1999; Haldane, 1997; Levin, Natalucci and Piger, 2004; Faust and Henderson, 2004).

The modelling efforts prescribing DIT in an open economy framework, where monetary policy cannot afford to be fully autonomous are more complex. Consistently with the assumptions stated above, central banks in small open economies that aspire to join a common currency area cannot set policy targets and adjust instruments in isolation. In this sense, they are 'target-takers'. In addition, they normally face an interest rate risk premium relative to the official rates determined by the large central banks. However in the long run, there is an equivalence of inflation targets between smaller economies and the common currency area, which can be stated as

$$
\bar{\pi}_{t+\kappa, t}^{d}-\bar{\pi}_{t+\kappa, t}^{f}=0
$$

The domestic long-term inflation target is denoted by $\bar{\pi}_{t+\kappa, t}^{d}$ and the foreign (euro area) target by $\bar{\pi}_{t+\kappa, t}^{f} ;$ both specified at time $t$ for $\kappa$-periods ahead.

In an alternative form, the target identity can be prescribed as

$$
\bar{\pi}_{t+\kappa, t}^{d}=\gamma \bar{\pi}_{t+\kappa, t}^{f}
$$

The $\gamma$ translator between foreign and domestic inflation targets is assumed to be equal to one if the perfect identity between both targets holds. However, some flexibility might be sought, thus the translator might slightly exceed unity, if a small converging economy needed to establish a safety cushion against possible external shocks for $\kappa$-periods ahead. Yet, such a cushion may not be a best-practice policy. It is because possible deviations between future realisations of domestic inflation in excess of the identical long-term target can be always explained to the public at large as a temporary shock that does not need to be corrected, unless it stems from a fundamental fiscal instability or other durable institutional deficiencies. An unequivocal target identity underpins policy-makers full commitment to monetary convergence, while a wider cushion built into the domestic inflation target is likely to water it down in the public's perception. 
In a backward-looking setting, a strict DIT operational framework, which does not take into consideration alternative targets (such as income growth) can be stated as

$$
\Delta \pi_{t}+\theta_{t}=\bar{\pi}_{t+\tau, t}+\beta_{i} \Delta i_{t+1}+\beta_{s} \Delta s_{t+1}
$$

The first-order autoregressive movements of inflation, short-term interest rates and domestic currency values of the euro are respectively: $\Delta \pi_{t}=\pi_{t}-\pi_{t-1}, \Delta i_{t+1}=i_{t+1}-i_{t}$ and $\Delta s_{t+1}=s_{t+1}-s_{t}$.

Eq. (3) reflects the first-order autoregressive inflation process as a function of two endogenous variables, namely the long-term inflation target and the inflation risk premium $\theta_{t}$, as well as the next period's interest rate and nominal exchange rate as exogenous variables. The historical inflation risk premium can be assessed as a difference between a smoothed inflation rate extrapolated from the past and the neutral nominal interest rate. Computed in this way, the inflation risk premium is in essence identical with the observed dynamic neutral real interest rate. In a forward-looking setting, the inflation risk premium can be also endogenised as it is likely to decline along with the expected gains in monetary policy credibility.

The policy relationship prescribed by Eq.(3) implies that, for instance, an observed surge in inflation might be counteracted by raising the next period's interest rate (as the adjustment in the policy instrument), or translated into the next period's domestic currency depreciation (increased $s_{t}$ ) if there is no change in the policy instrument, which means, the targeted shortterm interest rate. Thus by assumption $\beta_{i}+\beta_{s}=1$. If $\beta_{i}$ equals zero, the policy stance is neutral, allowing the national currency to depreciate.

A more dynamic version of policy reaction function prescribed by Eq. 3 can take into consideration exchange rate pass-through effects into inflation. A complete pass-through takes place when

$$
\beta_{s} \Delta s_{t-1}=\Delta \pi_{t+l}
$$

with the optimal pass-through period denoted by $l+1$. A partial pass-through is reflected by

$$
\beta_{s} \Delta s_{t-1}=\beta_{\lambda} \Delta \pi_{t+l}
$$


The pass-through effects can become neutralised by actual or expected interest rate increases; then, $\beta_{s}$ is equal zero.

As the DIT strategy evolves to a more advanced stage, it becomes increasingly important for a central bank to contain inflation by influencing the public's expectations. In order to increase sensitivity of actual inflation to inflation expectations, and thus to 'activate' the expectations channel of monetary policy transmission, a central bank gears its interest rate decisions to the deviations between the inflation forecast and the official target. Thus the policy becomes forward-looking. If the central bank still wishes to preserve its autonomy, the operational framework will focus on future expected or forecast variables and it can be specified as

$$
\Delta \pi_{t+\tau, t}+\theta_{t}=\bar{\pi}_{t+\tau, t}+\beta_{i} \Delta i_{t+1}+\beta_{s} \Delta s_{t+1}
$$

Reflected by $\Delta \pi_{t+\tau, t}$ is the inflation forecast for $\tau$-periods ahead, which is the time period corresponding with that of the inflation target.

By including the exchange rate variable, the reaction function prescribed by Eq. (5) reflects an open economy environment. It is a somewhat simplified version of more elaborate open economy inflation targeting models, which also encompass an output gap variable as an alternative policy target in a flexible inflation targeting setting. These models have been introduced to the literature by Ball (1999), expanded, among others, by Svensson (2000), and adopted to the environment of transition economies by Orlowski $(2001 ; 2005)$ and Golinelli and Rovelli (2005). They do not, however, incorporate the fundamental objectives faced by the economies converging to a common currency area. This gap may be filled by extending Eq. (5), which takes into consideration the common currency area (the eurozone) variables, namely, its long-term inflation target and forecast.

\section{The RIFT Framework}

By introducing the foreign inflation target and forecast variables, the candidate's central bank's reaction function becomes 


$$
\Delta \pi_{t+\tau, t}^{d}-\Delta \pi_{t+\tau, t}^{f}+\theta_{t}^{d}=\bar{\pi}_{t+\tau, t}^{d}-\bar{\pi}_{t+\tau, t}^{f}+\beta_{i} \Delta i_{t+1}^{d}+\beta_{s} \Delta s_{t+1}
$$

Superscripts $d$ and $f$ denote domestic and foreign variables respectively. The equivalence of longterm targets specified by Eq. (1) allows for their elimination from the examined reaction function. These long-term targets can be viewed in essence as the 'choice' variables, because the convergence tasks compel the candidate country's central bank to assume the long-term inflation target that is identical with the euro area inflation target. Consequently, the modified RIFT operational framework becomes

$$
\Delta \pi_{t+\tau, t}^{d}-\Delta \pi_{t+\tau, t}^{f}=-\theta_{t}^{d}+\beta_{i} \Delta i_{t+1}^{d}+\beta_{s} \Delta s_{t+1}
$$

It shall be noted that the identity between the long-term inflation targets can be only ensured when the domestic inflation risk premium $\theta_{t}^{d}$ cedes to exist. Since the domestic inflation risk premium is defined as an average excess variability of domestic inflation over the variability of foreign inflation in the observed recent period $t-k$, it can be proxied by a difference between the conditional variances of domestic and foreign inflation rates.

$$
\int_{t-k}^{t} \sigma_{t}^{2} d \kappa-\int_{t-k}^{t} \sigma_{t}^{2} d \kappa=\theta_{t}^{d}
$$

The conditional variances of domestic and foreign inflation rates during the $t-k$ period are denoted by $\sigma_{t}^{2}$ and $\sigma_{t}^{\prime 2}$ respectively. As noted above, a successful monetary convergence requires that the inflation risk premium is gradually reduced to zero, thus

$$
\lim \theta_{t} \rightarrow 0
$$

Completion of the dynamic process of minimising the inflation risk premium can be considered as a judicious requirement for a formal inception of the final passage toward adopting the euro. For this reason, the process of monetary convergence to a common currency system cannot begin 
prematurely, in the presence of a large inflation risk premium, which tends to precipitate shocks to nominal exchange rate (Orlowski, 2003; Csermely, 2004) as well as real exchange rates (Golinelli and Rovelli, 2005). A formal inception of the final stage of convergence to the euro may require an established prior record of policy credibility, which may be characterized as a 'foundational credibility'. Otherwise, a premature declaration of the final stage of convergence (that in practical terms can be exemplified by the formal entry to the ERMII) is likely to exacerbate both nominal and real shocks to economy stemming from the prevalent inflation risk premium.

The RIFT reaction function prescribed by Eq. (7) implies that a central bank of the converging country can either raise short-term interest rates or let the national currency to depreciate in response to an increase in the relative inflation forecast. It further assumes that in the long-run the domestic inflation risk premium will gradually dissipate. Therefore, the proposed policy framework shall be viewed as an advancement, not a replacement, of a strict DIT for which attainment of a low inflation target is a sole policy objective. Moreover, Eq. (7) can be considered as a policy rule, which offers several attractive advantages over interest rate rules that correspond with various open economy Taylor rules. Chief among these advantages is an explicit commitment to containing inflation, encompassed in the prescribed rule, which is rather questionable when a central bank follows a discretionary policy without rules or is restrained by interest rate rules. A central bank following the RIFT rule could raise interest rates in response to a growing relative inflation forecast in consistency with a Taylor rule. But contrary to such interest rate rule, it could also opt for allowing the national currency to depreciate if it were able to demonstrate that a feedback effect of depreciation into inflation expectations would be rather weak. In particular, the currency depreciation option could be considered if the exchange rate shock, along with a possible current inflation shock were viewed as only temporary, having no substantial bearing on inflation expectations. In any case, operational rules such as the RIFT functional responses are superior to strict interest rate (instrument) rules as they allow for a wider range of policy responses ${ }^{1}$. Specifically, they permit

\footnotetext{
${ }^{1}$ For this reason, Svensson (2003) argues that Taylor rules are seemingly impractical. It is because optimal reaction functions are always by far more complex than straightforward Taylor rules as they should allow policy makers to modify their commitment to policy responses with an arrival of new information. In principle, Svensson's argument is consistent with dynamic adjustments in policy commitment in a 'timeless perspective' proposed by Woodford (1999).
} 
a central bank to refrain from interest rate increases if new information about the transmission mechanism, mainly the exchange rate transmission channel, becomes available.

It can be further noted that the reaction function prescribed by Eq. (7) differs from more traditional models of central bank loss functions that emphasise a trade-off between disinflation and income growth as the only combination of alternative policy targets. As a matter of fact, a possible monetary policy objective of income creation can still be accounted for within the RIFT framework in a more dynamic, intertemporal setting. It is because the proposed policy is aimed at reducing the inflation risk premium (diminishing real interest rates) and gaining the policymakers credibility. A successful realisation of both objectives is likely to promote credit growth, thus ultimately stimulate consumer spending on durable goods and contribute to a more favourable climate for both domestic and foreign direct investment.

If the RIFT framework is to be devised as a monetary convergence criterion, it might be pragmatic to formulate it as a range rather than a point target. Specifically, the target range may permit the candidate's inflation forecast to overshoot the euro area forecast by, for instance, one percent. This means that a permissible criterion for the euro adoption would be a one-sided asymmetric range. Its lower boundary would be set at the perfect balance between the national and the euro area inflation forecasts, and the upper boundary would be at a one percent above it. A reasonably narrow range instead of a point target of the headline inflation forecast would provide a safety cushion against possible temporary inflation shocks seemingly attributable to sudden large capital inflows that are likely to be triggered by a formal announcement of the final passage toward the euro.

\section{Selected Indicator and Instrument Variables}

The RIFT framework prescribed by Eq. (7) is designed in principle as an extended version of DIT. It means that its practical implementation will have to be based on a set of indicator variables reflecting a large number of complex nominal and real functional relationships, as DIT policies always need to be backed by a range of elaborate monitoring tools. A comprehensive examination of all necessary indicator and instrument variables that would compose a complete and cohesive RIFT operational system goes far beyond the boundaries of this study. Therefore, this analysis focuses exclusively on the most essential, core policy variables supporting RIFT, namely, on the functional relationships that stem directly from the reaction function prescribed 
by Eq. (7). These functional relationships are viewed as policy monitoring rules that reflect interactions between the key indicator variables supporting RIFT. The main monitoring rules are based on exchange rate stability and money growth formulas, while the underlying instrument rule is a simplified interest rate function that is derived directly from Eq. (7). Examination of other indicator variables that ought to be taken into consideration in designing a comprehensive RIFT framework, mainly income growth, real exchange rate, real interest rate, current and capital account flows, etc. goes beyond the limits of this study. Moreover, this analysis is not aimed at investigating dynamic, intertemporal relationships between the examined variables that would signify the fundamental channels of monetary policy transmission within an advanced DIT framework. Thus by design, this analysis encompasses only the very essence of RIFT as a simple policy rule underpinning the policy-makers' firm commitment to monetary convergence to the euro.

With respect to the exchange rate stability objective, the proposed RIFT operational framework can be reformulated as a dynamic function of exchange rate fluctuations responding to the relative inflation forecast, the prevalent inflation risk premium, and the anticipated adjustment in the domestic interest rate. In addition, the expected currency depreciation (or appreciation) may be augmented by the exchange rate risk $\varphi_{t}$, which is technically assessed by the volatility of the exchange rate that is conditional on the macroeconomic fundamentals, including the relative inflation forecast, interest rates, and the inflation risk premium ${ }^{2}$. The exchange rate dynamics that take into consideration the exchange rate risk premium $\varphi_{t}$ can be expressed as

$$
\Delta s_{t+1}+\varphi_{t}=\delta_{\pi}\left(\Delta \pi_{t+\tau, t}^{d}-\Delta \pi_{t+\tau, t}^{f}\right)-\delta_{i} \Delta i_{t+\tau, t}^{d}+\delta_{\theta} \theta_{t}^{d}
$$

It remains debatable whether the time-varying currency volatility variable can be elevated to the role of a target variable that is ancillary to the inflation target, or merely considered as a policy indicator variable. The ability to reduce exchange rate variability has been in fact emphasised as an important criterion of a successful monetary convergence to the eurozone by

\footnotetext{
2 The time-varying exchange rate risk premium can be technically encapsulated by the conditional currency volatility in ARCH-class tests, which have been originally proposed by Engle, Lilien and Robbins (1987). The conditional variance may be included in the mean functional relationships such as the one prescribed by Eq. (10), which are generically referred to as GARCH-M models. For their description, see for instance Poon and Granger (2003) or Gourieroux and Jasiak (2001, chapter 6).
} 
both the architects of the Maastricht Treaty and the authors of several recent studies addressing this subject (Natalucci and Ravenna, 2003; Jonas, 2004; Orlowski, 2005). It seems however that upgrading the task of the exchange rate stability to the status of a formal policy goal, within a more flexible DIT framework, could precipitate some divergence between inflation and exchange rate stability targets. Yet the issue whether the objectives of containing inflation and reducing exchange rate volatility are contradictory or congruent deserves further exploration. Plausible areas of conflict between both objectives within the 'dual-target one-instrument' monetary policy strategy are examined by Jonas (2004). Perhaps most pronounced among them is a combination of currency appreciation and higher inflation in the presence of large capital inflows. Stronger national currency would instigate lowering interest rates, which subsequently could jeopardize attaining the inflation target. Adversely, raising interest rates by a central bank in response to inflationary pressures might result in currency appreciation and exacerbate exchange rate volatility. A similar conflict may arise when the observed currency appreciation is counteracted with foreign exchange market intervention. If the intervention is sterilised for the purpose of containing liquidity growth, the inflation target could possibly be breached, depending on the scale of the sterilised intervention.

Yet, in the absence of significant nominal shocks that are normally induced, for instance, by large capital inflows, both low inflation and exchange rate stability targets seem to be rather congruent. For instance, exchange rate stability is a contributing factor to an improved risk structure of capital inflows, thus it tends to promote foreign direct rather than portfolio investment. Upon their completion, foreign direct investment projects will normally increase domestic supply of goods and services, thereby reduce inflation. Such adjustment will certainly take place only if foreign direct investment does not entail a substantial productivity growth in the tradable goods sector and, along the lines of the Balassa-Samuelson Effect, does not lead to a higher price of non-tradables relative to tradables, and thus to higher overall inflation. Also, improved currency stability is likely to expand the time horizon of both tangible capital and portfolio investments, which will subsequently flatten the yield curve of both public and private securities, and thus reduce inflation expectations. In sum, conflicts between the stated policy targets are unlikely to emerge when Balassa-Samuelson effects become insignificant and large net capital inflows are contained thus no longer precipitate excessive nominal and real currency appreciation. 
Nevertheless, it seems that in order to alleviate potential policy conflicts between low inflation and exchange rate stability targets and, at the same time, to underpin a firm commitment to price stability as a key policy objective, the exchange rate stability ought to be treated as a policy indicator variable, rather than a target variable.

An equally controversial debate pertains to the alternative role of broad money growth and inflation targets. To this date, policies based on money growth targeting have not turned out to be a viable option for the NMS. These countries have all experienced a fast-track growth in monetisation (as measured by the ratio of broad money to nominal GDP) that has only now caught up with the EU comparable levels (Orlowski, 2004). In addition, money demand in these countries has been highly unstable (Fidrmuc and Korhonen, 2003) and this instability has been associated with perceived prevalence of Balassa-Samuelson effects (Egert, 2003; Egert, et.al. 2003; Crespo-Cuaresma, Fidrmuc and McDonald, 2003; Natalucci and Ravenna, 2003; DeGrauwe and Schnabl 2004). More favourable arguments for possible adoption of money growth rules can be derived from Kutan and Yigit (2002) who show increasing co-movements between real and monetary variables in the euro area and in NMS. In a similar vein, Orlowski (2004) argues that in spite of the unquestionable instability of income elasticity of money demand coefficients and a weak long-term cointegration between inflation and money in these economies, the future link between these two variables cannot be disqualified. His argument is subsequently reinforced by some preliminary evidence of short-run interactions between these two variables detected through the vector-error-correction tests.

The money growth model that might be used for policy monitoring purposes can be specified as

$$
\Delta m_{t+\tau-l, t}^{d}=\gamma_{\pi}\left(\Delta \pi_{t+\tau, t}^{d}-\Delta \pi_{t+\tau, t}^{f}\right)+\gamma_{\theta} \theta_{t}^{d}-\gamma_{i} \Delta i_{t+1}^{d}-\gamma_{s} \Delta s_{t+1}
$$

The time period $l$ reflects the optimum impact lag of money growth on inflation. By assumption, this impact lag is known to policy-makers. A possible adoption of this model for policy monitoring purposes requires at minimum to have a stable relationship between changes in money and in the relative inflation forecast. Such a link is yet to be established in the three NMS considering the evidence of high instability of money demand.

By its design, the RIFT reaction function can be viewed as a rule guiding two alternative policy responses to a change in the forecast of relative inflation. To reiterate, if there is an 
increase in domestic inflation expectations above those anticipated for the eurozone, the central bank of the candidate country may either raise interest rates or allow the national currency to depreciate. Consistently, if it chooses to respond by raising interest rates, its actions may be guided by an implicit instrument rule that is derived from Eq. (7), which can be specified as

$$
\Delta i_{t+1}^{d}=\alpha_{\pi}\left(\Delta \pi_{t+\tau, t}^{d}-\Delta \pi_{t+\tau, t}^{f}\right)+\alpha_{\theta} \theta_{t}^{d}-\alpha_{s} \Delta s_{t+1}
$$

The component $\alpha_{\theta} \theta_{t}^{d}$ can be viewed as a 'neutral' rate of interest, using the terminology consistent with the widely discussed Taylor-type interest rate rule formulas. By assumption, to reflect conditions of an economy converging to a common currency system, the neutral interest rate is linked with the inflation risk premium.

As discussed in Section 3, using Eq. (12) as a strict instrument rule for guiding monetary policy in an economy converging to a common currency system may prove to be rather impractical. A firm instrument rule requires policy-makers to have a full knowledge about monetary policy transmission channels at any point in time (Svensson, 2003). In particular, they need to have full information about the stable credit channel of policy transmission. Otherwise, policy adjustments bound by a prescribed interest rate rule may lead to destabilizing effects. With this in mind, instrument rules, even in the forward-looking setting suggested by Eq. (12), have a limited applicability in the NMS converging to the eurozone. It is because credit channels and interest rate pass-through effects are highly unstable and very hard to predict in these economies as proven by Crespo-Cuaresma, Égert and Reininger (2004).

\section{Empirical Record on Inflation Convergence}

Implementation of the proposed RIFT framework can become effective only if policy-makers have a full knowledge about interactions between the above-examined key monetary policy variables. Specifically, they need to be informed about optimal adjustment lags between interest rates and inflation, with a reasonable margin of error, in order to devise appropriate prior interest rate adjustments to meet the future inflation target. A full knowledge about transmission of exchange rates into inflation is also indispensable. If the actual response lags were subject to large, unpredictable errors and the relationship between inflation, interest rates and exchange 
rates were highly unstable, forward-looking policy decisions implied by the RIFT framework could lead to unintended outcomes. Moreover, since RIFT relies on inflation forecasts, monetary authorities should have a reliable methodology to prepare such forecasts, which is also fully disclosed to the public at large. If these prerequisites are met, inflation expectations of the central bank and the private sector will become fully synchronised thus making the RIFT implementation feasible.

Recognising the importance of such prerequisites, the empirical section of this study is intended to demonstrate whether there has been a stable relationship between changes in the expected future inflation relative to the eurozone, the observed volatility of the exchange rate and the actual changes in interest rates. If interactions between these variables are stable, introduction of the RIFT operational framework could be possible. As indicated above, the empirical exercise is carried for the three euro candidate countries that are currently pursuing policies based on DIT. The tested variables include the differential in the candidate's inflation forecast vis-à-vis Germany, its short-term interest rate, and nominal exchange rate, expressed in terms of national currency value relative to euro. Therefore, the empirical testing is aimed at detecting a stable relationship between the target variable, the instrument variable, and the crucial indicator variable from the standpoint of convergence to the euro. Stability between these variables is tested by employing autoregressive conditional heteroscedasticity ARCH-class models.

The main functional relationship between the three investigated variables is stated as

$$
\Delta \pi_{t+\tau, t}^{d}-\Delta \pi_{t+\tau, t}^{f}=\beta_{0}+\beta_{i} \Delta i_{t}^{d}+\beta_{s} \Delta s_{t+n}+\varepsilon_{t}
$$

Eq. (13) is the mean equation of the threshold ARCH or TARCH model composed of Eqs. (13) and (14). In this functional relationship $s_{t}$ is the $\log$ of the national currency value of one euro and $n$ denotes the optimal lag between the change in the exchange rate and its impact on the relative inflation forecast.

The TARCH conditional variance equation enables to measure the impact of volatility subcomponents. It is stated as

$$
\sigma_{t}^{2}=\omega+\sum_{l=1}^{p} \beta_{l} \varepsilon_{t-l}^{\prime 2}+\sum_{j=1}^{q} \beta_{j} \sigma_{t-j}^{2}+\sum_{k=1}^{r} \beta_{k} \varepsilon_{t-k}^{\prime 2} \Gamma_{t-k}
$$


Thus in essence, the testable empirical model investigating interactions between the relative inflation forecast for $\tau$-periods ahead, current period nominal interest rates and the $n$-period forwarded nominal exchange rate is composed of the mean equation (13) and the conditional variance equation (14) formulated as a $\operatorname{TARCH}(p, q, r)$ process ${ }^{3}$. The conditional variance equation consists of the ARCH term in the order of ' $\mathrm{p}$ ' represented by $\sum_{l=1}^{p} \beta_{l} \varepsilon_{t-l}^{\prime 2}$, the q-order GARCH term $\sum_{j=1}^{q} \beta_{j} \sigma_{t-j}^{2}$, and the leverage asymmetric r-order TARCH term $\sum_{k=1}^{r} \beta_{k} \varepsilon_{t-k}^{\prime 2} \Gamma_{t-k}$. The ARCH term shows the impact of the error variance in the previous period (or periods) on the current period error variance. Thus it allows evaluating the impact of 'innovations' from the previous periods (up to the q-order) on the conditional variance. The GARCH term reflects the degree of persistency in volatility. It measures the impact of the forecast variance from the previous period on the current conditional variance. The leverage effect is captured by the asymmetric TARCH term (to the k-order), in which $\Gamma_{t-k}$ are k-period dummy variables assuming the value of one for all the observed negative shocks $\left(\varepsilon_{t-k}^{\prime}<0\right)$ and zero for the positive ones. A negative value of the estimated leverage effect coefficient $\beta_{k}$ implies that the negative news or innovations raise the subsequent volatility rate more than the positive news. In addition, a positive value of the estimated coefficient indicates propagation of the subsequent conditional volatility, thus its negative estimated value is a more favourable finding for policy-makers as it implies a diminishing volatility. Another important stability indicator is the sum of ARCH and GARCH terms. If it is less than one, there is a volatility convergence to the steady-state.

The results of selected empirical tests are shown in Table 1. It shall be noted that the presented tests have been carefully chosen from the large number of alternative ones, all of which have been based on different data generating process (DGP) assumptions. The tests have been conducted for the Czech Republic, Poland and Hungary for the sample period January 1995 - June 2004. Their results are highly sensitive to DGP assumptions in terms of the applied generalized error distribution (GED) parameters, different lag operators of the three examined

\footnotetext{
${ }^{3}$ An overview of various ARCH-class models along with an overview of their applications and a summary of empirical results can be found in Poon and Granger (2003). The ARCH-class models originated from the seminal work of Robert Engle who gives their worthy noting synthesis in his Nobel Prize acceptance lecture (Engle, 2004). These econometric models have been applied for the purpose of evaluating various categories of financial risk in the NMS by Matoušek and Taci (2003); Orlowski (2003 and 2005); and Valachy and Kočenda (2003).
} 
variables, and the orders of $\mathrm{ARCH}, \mathrm{GARCH}$ and TARCH terms. GED parameters have been determined as a result of bootstrapping the test statistics since the GARCH conditional normality assumptions have been violated in the cases of the Czech Republic and Poland. The evidence of high sensitivity to DGP assumptions implies that there are significant systemic differences between the three examined countries that drive the process prescribed by Eqs. (13) and (14), but it also indicates that a larger number of observations may be required to achieve more robust, uniform results. By design, observations preceding January 1995 have been excluded from this exercise due to prevalence of hard currency pegs and other rigidities affecting interest rates and inflation rates in these countries at the early stage of the economic transition. It shall be further noted that all the tested variables have been entered in first-differenced terms as they are all nonstationary at their levels. Moreover, the relative inflation rates have been exponentially smoothed with an appropriate Holt-Winters parameter, and then, forwarded with different optimal time lags. The forwarded inflation differentials vis-à-vis Germany are treated as a proxy for relative inflation forecasts, since the central banks in question did not publish official inflation forecasts during the examined sample period (with the exception of the CNB in its recent quarterly inflation reports). In addition, the conditional density of the examined series is rather thin-tailed $(\mathrm{GED}=3)$ in the cases of the Czech Republic and Poland, thus it displays a lower probability mass in the tails than the normal (Gaussian) distribution and suggests that most of the shocks to volatility have not been destabilising. However, this finding may stem from the application of lower frequency (monthly) data and implies that a larger number of observations is needed to produce more robust stability results ${ }^{4}$.

..... insert Table 1 around here .....

The presented test results reveal diverse behavioural features of the inflation forecast differential as a function of changes in short-term interest rates and spot exchange rates in the three examined countries. The first, rather paradoxical finding for the Czech Republic is a positive sign of the statistically significant constant terms in the mean equation, which suggests

\footnotetext{
${ }^{4}$ Inclusion of non-Gaussian distribution parameters is an important feature of inflation forecast targeting practices, as argued by Svensson $(1999 ; 2003)$. It is because policy transmission mechanisms are intrinsically non-linear and non-additive thus a certainty-equivalence that is associated with a linear transmission is no longer applicable. Therefore, a forecast targeting procedure should not be restricted to the mean forecast only, but it should also consist of a conditional probability distribution of the target variables.
} 
that the conditional inflation risk premium relative to Germany's inflation is already negative. Also perplexing is the contemporaneous combination of the inflation differential and the Czech koruna appreciation, which might be explained by the pro-inflationary impact of large capital inflows that affected the country particularly during 1995-1997 (Brada and Kutan, 1999). As it can be reasonably expected in a DIT environment, interest rate adjustments in the preceding period do react significantly and effectively to the expected one-period-ahead inflation differential. The estimated conditional variance equation coefficients show that the inflation forecast volatility in the Czech Republic is extremely persistent (as proven by the GARCH (1) coefficient exceeding unity) and it does not seem to converge to the steady-state. This does not indicate an advancement of the Czech monetary stability. The conditional volatility is additionally affected by shocks or 'surprises' to volatility in the preceding period (a significant $\mathrm{ARCH}(1)$ term) and it is also subject to asymmetric shocks (a strong TARCH(1) effect). On a positive note, the negative sign of the TARCH coefficient implies that asymmetric shocks to the examined inflation process tend to reduce the subsequent conditional volatility; apparently, they seem to be successfully managed by the CNB.

A somewhat different functional relationship is detected for Poland. The estimated inflation risk premium is significant and negative, which suggests that the relative inflation forecast has been in fact diminishing. This proves that the policy of strict inflation targeting, which has been implemented by applying high real interest rates, has in fact reached the goal of containing domestic inflation relative to that in the euro area. In addition, interest rate increases seem to react to upswings in the relative inflation forecast for three-periods-ahead, although to a modest degree as the estimated $\beta_{i}$ is rather insignificant. Unlike in the Czech koruna case, the Polish zloty clearly depreciates in response to the projected inflation differential. This suggests prevalence of a relatively well-defined exchange rate channel of monetary policy transmission in Poland, contrary to the Czech and Hungarian cases. Moreover, the conditional volatility of the inflation differential in Poland is highly persistent. Yet it seems to be converging to the steadystate, albeit very slowly, as implied by the observed sum of ARCH and GARCH terms. The impact of innovations to volatility remains to be ambiguous. There is a strong corrective effect associated with the third-order ARCH term, but a propagation of volatility related to higher-order 
ARCH terms. Thus evidently, the conditional volatility dynamics for Poland are complex and hard to specify ${ }^{5}$.

The observed interactions between the tested variables in Hungary are also distinctive. The inflation risk premium is quite large, although less pronounced than in Poland. Interest rate reactions to the expected inflation differential are as strong as in the other two countries, but the exchange rate effect seems to be rather weak, perhaps due to the absence of flexibility during the first six years of the examined sample period. The crawling devaluation system with a narrow $(+/-2.25 \%)$ band of permitted fluctuations apparently restrained volatility transmission between the inflation differential and the exchange rate. In addition, volatility of the relative inflation forecast is highly persistent and not affected by innovations or asymmetric shocks from preceding periods. Since the GARCH(1) coefficient is less than one, a slow convergence of the conditional volatility of the inflation differential is evident.

On a final note, the mean change in the smoothed inflation differential has a negative sign in all three NMS cases implying a convergence of domestic to the German headline inflation. This convergence effect is most pronounced in Poland, followed by Hungary, and the least pronounced in the Czech Republic, which is understandable since the Czech CPI-based inflation has been consistently the lowest during the chosen sample period. As it is routinely the case in ARCH-class tests involving financial market variables (Poon and Granger, 2003), the $\mathrm{R}^{2}$ of the regressions shown in Table 1 are very low, reflecting the fact that the relative inflation forecast is a rather noisy volatility proxy. Nevertheless, due to their high statistical significance, the volatility subcomponents provide valuable information about the inflation process that is useful for preparing optimal forecasts and for designing effective inflation targeting strategies in these countries.

In hindsight, the presented empirical analysis shows that it is possible to determine a stable relationship between interest rates, exchange rates and the relative inflation forecasts in the examined euro candidate countries, however, only after a careful choice of DGP assumptions. Although it is limited to a three-variable, not highly robust setting, the presented evidence of monetary stability seems to suggest that a formal adoption of the proposed RIFT operational framework is entirely possible. However, its inception needs to be backed by the appropriate public announcement and the policy makers' full commitment to its implementation. The new

\footnotetext{
${ }^{5}$ It is worthy noting that alternative tests for Poland based on various DGP assumptions consistently suggest pronounced negative third-order and positive fourth-order ARCH effects, which implies that the lags in the conditional volatility between the tested variables are highly consistent.
} 
policy regime needs to be understood by both the policy makers and the public at large as a viable extension of the present, rather rudimentary DIT policies, from the standpoint of being conducive to a successful monetary convergence to the euro.

\section{A Synthesis}

This study advances inflation targeting strategies in NMS that are seemingly conducive to adopting the euro. The proposed monetary policy regime is based on the operational framework of targeting the differentials between the candidate and the eurozone inflation forecasts. A key assumption underlying such policy strategy is the identity between the long-term inflation targets of the candidate and the eurozone. An explicit statement and a public disclosure of the long-term target identity will highlight the central bank's commitment to adopting the euro and will reinforce the public support for the convergence program. The main prerequisite for the introduction of the RIFT operational framework is a prior record of monetary stability. At minimum, a functional relationship between the inflation forecast, interest rates and the exchange rate ought to be well defined and transmission of changes in interest rates and the exchange rate into anticipated inflation should be known to policy-makers in NMS. Such prior knowledge is indispensable for a successful implementation of RIFT.

The empirical analysis shows that it is possible to determine functional stability between key policy variables of the RIFT framework in the three examined NMS, although the outcomes of the ARCH-class tests for the Czech Republic, Poland and Hungary are very sensitive to DGP assumptions. The tests show diverse interactions between short-term interest rates, exchange rates and relative inflation forecasts, indicating vast systemic differences between these countries. Therefore, specific rules and means of conducting the proposed RIFT policy will have to be carefully tailored to the pronounced institutional and behavioural differences within the analysed group of countries.

It shall be further noted that the RIFT framework is not contradictory to the restrictions on monetary policy autonomy imposed by the official Maastricht convergence criteria and by the stipulations of the ERMII mechanism; providing that the band of permitted currency fluctuations will be maintained at a wide $+/-15$ percent range around the central predetermined parity rate. The wide band is likely to provide a sufficient degree of exchange rate flexibility that will enable the euro candidates to pursue policies based on RIFT. However, this analysis emphasises that 
monetary policies on the final passage toward the euro will have to assume inflation targets as the focal policy goal with the exchange rate stability treated as a policy indicator variable.

It seems that there is a sufficient time remaining to the intended euro adoption for NMS to modify their existing inflation targeting regimes along the lines suggested by the RIFT operational framework. Specific guidelines and prescriptions for RIFT are still to be discussed and articulated in order to make policies to this end entirely possible. 


\section{References}

Ball, L., 1999. Policy rules for open economies. In: Taylor, J. (Ed.), Monetary Policy Rules, University of Chicago Press. Chicago, Illinois, pp. 127-156.

Bernanke, B.S., Laubach, T., Mishkin, F.S., Posen, A.S., 1999. Inflation targeting: lessons from the international experience. Princeton University Press, Princeton, NJ.

Brada, J.C., Kutan, A.M., 1999. The persistence of moderate inflation in the Czech Republic and the koruna crisis of May 1997, Post-Soviet Geography and Economics 40 (2), 121-134.

Christofferssen, P.R., Wescott, R.S., 1999. Is Poland ready for inflation targeting? International Monetary Fund Working Paper No. WP/99/41. Washington, D.C.

Corker, R.J., Beaumont, C., vanElkan, R., Iakova, D., 2000. Exchange rate regimes in selected advanced transition economies: Coping with transition, capital flows, and EU accession. International Monetary Fund: Policy Discussion Paper No. 2000/3. Washington, D.C.

Crespo-Cuaresma, J., Égert, B., Reininger, T., 2004. Interest rate pass-through in new EU Member States: the Czech Republic, Hungary and Poland. University of Michigan - William Davidson Institute Working Paper No. 671.

Crespo-Cuaresma, J., Fidrmuc, J., McDonald, R., 2003. The monetary approach to exchange rates: panel data evidence for selected CEEC's. Oesterreichische Nationalbank: Focus on Transition 2, 138-151.

Csermely, A., 2004. Convergence expectations and convergence strategies: lessons from the Hungarian experience in the pre-EU period. Comparative Economic Studies 46 (1), 104-126.

De Grauwe, P., Schnabl, G., 2004. Nominal versus real convergence wit respect to EMU accession: How to cope with the Balassa-Samuelson dilemma. Paper to the International Atlantic Economic Society convention, Lisbon, March 11-14.

Égert, B., 2003. Assessing Equilibrium Exchange Rates in CEE Acceding Countries: Can We Have DEER with BEER without FEER? A Critical Survey of the Literature. Oesterreichische Nationalbank: Focus on Transition 2, 38-106.

Égert, B., I. Drine, K. Lommatzsch and C. Rault. 2003. The Balassa-Samuelson effect in Central and Eastern Europe: Myth or reality?. Journal of Comparative Economics 31(3), 552-572.

Engle, R., 2004. Risk and volatility: Econometric models and financial practice. American Economic Review 94 (3), 405-420. 
Engle, R., Lilien D., Robbins R., 1987. Estimating time-varying risk premia in the term structure: The ARCH-M model. Econometrica 55 (1), 391-407.

Faust, J., Henderson, D.W., 2004. Is inflation targeting best-practice monetary policy? In: Inflation targeting, prospects and problems. The Federal Reserve Bank of St. Louis Review, $86(4), 117-144$.

Fidrmuc, J., Korhonen, I., 2003. Similarity of supply and demand shocks between the Euro Area and the CEECs. Economic Systems 27 (3), 313-334.

Golinelli, R., Rovelli, R., 2005. Monetary policy transmission, interest rate rules and inflation targeting in three transition countries. Journal of Banking and Finance 29 (1), 183-201.

Gourieroux, C., Jasiak, J., 2001. Financial econometrics: Problems, models, and methods. Princeton University Press, Princeton, NJ.

Haldane, A.G., 1997. Some issues in inflation targeting. Bank of England, London, U.K.

Jonas, J., 2004. Euro adoption and Maastricht criteria: Rules or discretion?. University of BonnCenter for European Integration Studies (ZEI): Working Paper B14/2004.

Jonas, J., Mishkin F.S., 2003. Inflation targeting in transition economies: Experience and prospects. NBER Working Paper, No. 9667.

Kutan, A., M., Yigit, T.M., 2002. Nominal and real stochastic convergence within the transition economies and to the European Union: evidence from panel data. University of Bonn-Center for European Integration Studies (ZEI): Working Paper B21/2002.

Levin, A.T., Natalucci, F.M., Piger, J.R., 2004. The macroeconomic effects of inflation targeting. In: Inflation targeting, prospects and problems. The Federal Reserve Bank of St. Louis Review, 86 (4), 51-80.

Masson, P.R., 1999. Monetary and exchange rate policy of transition economies of Central and Eastern Europe after the launch of EMU, IMF Policy Discussion Paper No. PDP/99/5, International Monetary Fund, Washington, D.C.

Matousek, R., Taci, A., 2003. Direct inflation targeting and nominal convergence: The Czech case. Open Economies Review, 14 (3), 269-283.

Mishkin, F.S., 2000. Inflation targeting in emerging-market countries. The American Economic Review: AEA Papers and Proceedings 90 (2), 105-109.

Natalucci, F. M., \& Ravenna F., 2003. The Road to adopting the Euro: Monetary policies and exchange rate regimes in EU accession countries. The Federal Reserve Board - Division of International Finance, Washington, D.C., mimeo. 
Orlowski, L.T., 2001. From inflation targeting to the euro-peg: a model of monetary convergence for transition economies. Economic Systems 25 (3), 233-251.

Orlowski, L.T., 2003. Monetary convergence and risk premiums in the EU accession countries. Open Economies Review 14 (3), 251-267.

Orlowski, L.T., 2004. Money rules for the eurozone candidate countries. Journal of Policy Modeling, 26 (7), 817-837.

Orlowski, L.T., 2005. Monetary convergence of the EU accession countries to the eurozone: A theoretical framework and policy implications. Journal of Banking and Finance 29 (1), 203225.

Poon, S.H., Granger, C.W.J., 2003. Forecasting volatility in financial markets: A review. Journal of Economic Literature 41(2), 478-539.

Svensson, L.E.O., 1999. Inflation targeting as a monetary policy rule. Journal of Monetary Economics 43 (3), 607-654.

Svensson, L.E.O., 2000. Open-economy inflation targeting. Journal of International Economics $50(2), 155-183$.

Svensson, L.E.O., 2003. What is wrong with Taylor rules?: Using judgment in monetary policy through targeting rules. Journal of Economic Literature 41(2), 426-477.

Valachy, J., Kočenda, E., 2003. Exchange rate regimes and volatility: Comparison of the Snake and Visegrad. University of Michigan - William Davidson Institute Working Paper No. 622.

Woodford, M., 1999. Commentary: How should monetary policy be conducted in an era of price stability? In: New Challenges for Monetary Policy. Federal Reserve Bank of Kansas City, Kansas City, Missouri, pp. 277-316. 
Table 1: Summary of ARCH-class Tests of Eqs.(13) and (14) for the Czech Republic, Poland and Hungary (January 1995 - June 2004 sample period).

\begin{tabular}{|c|c|c|c|}
\hline & Czech Republic & Poland & Hungary \\
\hline $\begin{array}{c}\text { Normality Assumptions: } \\
\text { GED parameter }\end{array}$ & 3.0 & 3.0 & $\begin{array}{c}2.0 \\
\text { (Gaussian } \\
\text { distr.) }\end{array}$ \\
\hline $\begin{array}{c}\text { Holt-Winters } \beta \text {-smoothing parameter } \\
\text { for inflation differential }\end{array}$ & 0.27 & 0.46 & 0.45 \\
\hline $\begin{array}{c}\text { Applied lag operators: } \\
\Delta \text { inflation differential } \\
\Delta \text { interest rate } \\
\Delta \text { log of spot exchange rate } \\
\end{array}$ & $\begin{array}{c}0 \\
-1 \\
0 \\
\end{array}$ & $\begin{array}{c}+3 \\
0 \\
0 \\
\end{array}$ & $\begin{array}{c}+2 \\
0 \\
0\end{array}$ \\
\hline $\begin{array}{l}\text { Mean equation estimated coefficients } \\
\text { Constant }\left(\beta_{0}\right) \\
\beta_{i} \\
\beta_{s}\end{array}$ & $\begin{array}{c}0.108(4.04) \\
0.496(4.01) \\
-7.236(-1.88)\end{array}$ & $\begin{array}{l}-0.205(-2.62) \\
0.179(1.64) \\
7.221(2.13)\end{array}$ & $\begin{array}{r}-0.113(-1.45) \\
0.273(2.42) \\
-1.585(-0.31)\end{array}$ \\
\hline Variance equation est. coefficients & & & \\
\hline $\begin{array}{l}\text { Constant } \\
\text { ARCH } 1 \text { st order } \\
\text { ARCH } 2^{\text {nd }} \text { order } \\
\text { ARCH } 3^{\text {rd }} \text { order } \\
\text { ARCH } 4^{\text {th }} \text { order }\end{array}$ & $\begin{array}{l}0.024(1.60) \\
0.162(7.41) \\
\text { na } \\
\text { na } \\
\text { na }\end{array}$ & $\begin{array}{c}0.015(1.20) \\
0.102(0.98) \\
0.007(0.05) \\
-0.248(-2.09) \\
0.161(3.62)\end{array}$ & $\begin{array}{c}0.070(4.31) \\
-0.053(-1.32) \\
\text { na } \\
\text { na } \\
\text { na }\end{array}$ \\
\hline TARCH $1^{\text {st }}$ order & $-0.333(-14.08)$ & na & na \\
\hline GARCH $1^{\text {st }}$ order & $1.009(42.39)$ & $0.934(17.16)$ & $0.894(25.30)$ \\
\hline $\begin{array}{c}\text { Mean } \Delta \text { inflation differential } \\
\text { St. deviation of inflation differential } \\
\text { Log likelihood } \\
\text { AIC } \\
R \text {-squared }\end{array}$ & $\begin{array}{c}-0.046 \\
0.885 \\
-123.15 \\
2.41 \\
0.078\end{array}$ & $\begin{array}{c}-0.277 \\
0.847 \\
-123.11 \\
2.42 \\
0.043\end{array}$ & $\begin{array}{c}-0.144 \\
0.964 \\
-128.47 \\
2.38 \\
0.122\end{array}$ \\
\hline
\end{tabular}

Notes: z-statistics are in parentheses, AIC is Akaike information criterion. Nominal exchange rates are average monthly national currency values of the euro, and prior to 1999, of the German mark adjusted by its irrevocable conversion rate to the euro of 1.95583. Inflation differentials are monthly year-on-year national vis-à-vis German headline CPI inflation rates, smoothed exponentially with Holt-Winters.

Source: Own calculations based on the IMF, the Bundesbank, CNB, NBP and NBH data. 


\section{DAVIDSON INSTITUTE WORKING PAPER SERIES - Most Recent Papers}

The entire Working Paper Series may be downloaded free of charge at: www.wdi.bus.umich.edu

CURRENT AS OF 2/16/05

\begin{tabular}{|c|c|c|}
\hline Publication & Authors & Date \\
\hline $\begin{array}{l}\text { No. 754: Targeting Relative Inflation Forecast as Monetary Policy } \\
\text { Framework for Adopting Euro }\end{array}$ & Lucjan T. Orlowski & Feb. 2005 \\
\hline $\begin{array}{l}\text { No. 753: Internet Entrepreneurship: Networks and Performance of } \\
\text { Internet Ventures In China }\end{array}$ & Bat Batjargal & Feb. 2005 \\
\hline $\begin{array}{l}\text { No. 752: Network Triads: Transitivity, Referral and Venture Capital } \\
\text { Decisions in China and Russia }\end{array}$ & Bat Batjargal & Feb. 2005 \\
\hline $\begin{array}{l}\text { No. 751: Software Entrepreneurship: Knowledge Networks and } \\
\text { Performance Of Software Ventures In China and Russia }\end{array}$ & Bat Batjargal & Feb. 2005 \\
\hline $\begin{array}{l}\text { No. 750: Retained State Shareholding in Chinese PLCs: Does } \\
\text { Government Ownership Reduce Corporate Value? }\end{array}$ & Lihui Tian and Saul Estrin & Feb. 2005 \\
\hline No. 749: Financial Development and Technology & Solomon Tadesse & Feb. 2005 \\
\hline No. 748: Banking Fragility and Disclosure: International Evidence & Solomon Tadesse & Feb. 2005 \\
\hline $\begin{array}{l}\text { No. 747: Consolidation, Scale Economies and Technological Change in } \\
\text { Japanese Banking }\end{array}$ & Solomon Tadesse & Feb. 2005 \\
\hline $\begin{array}{l}\text { No. 746: Trade Creation and Diversion Effects of Europe’s Regional } \\
\text { Liberalization Agreements }\end{array}$ & Yener Kandogan & Feb. 2005 \\
\hline No. 745: Quality of Institutions, Credit Markets and Bankruptcy & Christa Hainz & Feb. 2005 \\
\hline $\begin{array}{l}\text { No. 744: How Transition Paths Differ: Enterprise Performance in Russia } \\
\text { and China }\end{array}$ & Sumon Bhaumik and Saul Estrin & Jan. 2005 \\
\hline $\begin{array}{l}\text { No. 743: Inflation Targeting, Between Rhetoric and Reality. The Case } \\
\text { of Transition Economies }\end{array}$ & Daniel Daianu and Laurian Lungu & Jan. 2005 \\
\hline $\begin{array}{l}\text { No. 742: How Does Law Affect Finance? An Empirical Examination of } \\
\text { Tunneling in an Emerging Market }\end{array}$ & $\begin{array}{l}\text { Vladimir Atanasov, Conrad S. } \\
\text { Ciccotello, \& Stanley B. Gyoshev }\end{array}$ & Jan. 2005 \\
\hline $\begin{array}{l}\text { No. 741: Do Insider Trading Laws Matter? Some Preliminary } \\
\text { Comparative Evidence }\end{array}$ & Laura Nyantung Beny & Jan. 2005 \\
\hline $\begin{array}{l}\text { No. 740: Autopsy on an Empire: Understanding Mortality in Russia and } \\
\text { the Former Soviet Union }\end{array}$ & $\begin{array}{l}\text { Elizabeth Brainerd and David M. } \\
\text { Cutler }\end{array}$ & Jan. 2005 \\
\hline $\begin{array}{l}\text { No. 739: Not Separate, Not Equal: Poverty and Inequality in Post- } \\
\text { Apartheid South Africa }\end{array}$ & $\begin{array}{l}\text { Johannes G. Hoogeveen and Berk } \\
\text { Özler }\end{array}$ & Jan. 2005 \\
\hline $\begin{array}{l}\text { No. 738: The Marketing Structure in Agribusiness during the Transition } \\
\text { in Bulgaria }\end{array}$ & $\begin{array}{l}\text { Steve Murray, Yordan Staykov, } \\
\text { and Valentin Katzerov }\end{array}$ & Jan. 2005 \\
\hline No. 737: Passive Creditors & $\begin{array}{l}\text { Koen Schoors and Konstantin } \\
\text { Sonin }\end{array}$ & Jan. 2005 \\
\hline $\begin{array}{l}\text { No. 736: From a currency board to the euro: Public attitudes toward } \\
\text { unilateral euroization in Bulgaria }\end{array}$ & Neven T. Valev & Jan. 2005 \\
\hline No. 735: Dictators and Their Viziers: Agency Problems in Dictatorships & $\begin{array}{l}\text { Georgy Egorov and Konstantin } \\
\text { Sonin }\end{array}$ & Jan. 2005 \\
\hline $\begin{array}{l}\text { No. 734: Foreign Investment, Corporate Ownership, and Development: } \\
\text { Are Firms in Emerging Markets Catching Up to the World Standard? }\end{array}$ & $\begin{array}{l}\text { Klara Sabirianova, Jan Svejnar, } \\
\text { and Katherine Terrell }\end{array}$ & Jan. 2005 \\
\hline $\begin{array}{l}\text { No. 733: Businessman Candidates: Special-Interest Politics in Weakly } \\
\text { Institutionalized Environments }\end{array}$ & $\begin{array}{l}\text { Scott Gehlbach and Konstantin } \\
\text { Sonin }\end{array}$ & Dec. 2004 \\
\hline $\begin{array}{l}\text { No. 732: Measuring the Institutional Change of the Monetary Regime } \\
\text { in a Political Economy Perspective }\end{array}$ & $\begin{array}{l}\text { Nikolay Nenovsky and Yorgos } \\
\text { Rizopoulos }\end{array}$ & Dec. 2004 \\
\hline $\begin{array}{l}\text { No. 731: Impact of Regulated Price Adjustments on Price Variability in } \\
\text { a Very Low Inflation Transition Economy: Case of Armenia }\end{array}$ & Aghassi Mkrtchyan & Nov. 2004 \\
\hline $\begin{array}{l}\text { No. 730: Reform, FDI and Economic Growth: Tale of the Tortoise and } \\
\text { the Hare }\end{array}$ & $\begin{array}{l}\text { Bruno Merlevede and Koen } \\
\text { Schoors }\end{array}$ & Nov. 2004 \\
\hline $\begin{array}{l}\text { No. 729: The Effects of Transition and Political Instability On Foreign } \\
\text { Direct Investment Inflows: Central Europe and the Balkans }\end{array}$ & $\begin{array}{l}\text { Josef C. Brada, Ali M. Kutan, } \\
\text { and Taner M. Yigit }\end{array}$ & Nov. 2004 \\
\hline $\begin{array}{l}\text { No. 728: Institutional Distance and International Business Strategies } \\
\text { in Emerging Economies }\end{array}$ & $\begin{array}{l}\text { Delia Ionascu, Klaus E. Meyer, } \\
\text { and Saul Erstin }\end{array}$ & Nov. 2004 \\
\hline No. 727: Explaining Patterns of Corruption in the Russian Regions & $\begin{array}{l}\text { Phyllis Dininio and Robert W. } \\
\text { Orttung }\end{array}$ & Nov. 2004 \\
\hline
\end{tabular}

